\title{
National Schools of the 20th Century: Cultural Identity or Conceptual Choice
}

\author{
Elizaveta Malinovskaya \\ Art Gallery ARK \\ Almaty, Kazakhstan \\ eliz.mln@gmail.com
}

\begin{abstract}
The idea of contemporary art of the east as a creative periphery and the product of purely foreign influences is unsubstantiated and false. The formation of original schools can be of a programmatic nature in connection with the specificity of professional activity - the presence of creative consciousness, conceptual directions, both for the inheritance of traditions, and for external borrowings, their synthesis. There is an active correlation with foreign cultures, expanding aesthetic fronts of national art. These socio-cultural dynamics form qualitative components and the phenomenon of the "national school", not the abstract concept of "national culture", symbolizing the "scene of action" nor the specifics of the processes. For their understanding, it is necessary to reveal a complexity of factors of professional creative model of the school formation, the parameters of its self-determination and cultural-shaping role at all stages of formation of modern national architecture of the Soviet East, beginning with the design-construction situation of the 1920s.
\end{abstract}

Keywords-Central Asia; architectural heritage; innovations; theory and practice; 1920-1930s

\section{INTRODUCTION}

The current stage of development regarding the world cultural community is marked by the process of intensive formation of national schools. A special place among them is occupied by those who came to professional creativity on the basis of mutual adaptation of different types of arts (West East, professional - popular, modern - folklore). At the same time, taking into account established historical and cultural contacts of Central Asia, it is necessary to analyze the littleresearched theory and practice of local projectors throughout the region during the period under consideration, as well as the activity of the Center's architects for whom mastering local traditions proved to be creatively fruitful.

Regional theorists and practitioners L.N. Voronin, B.N. Zasypkin, S.N. Polupanov, G.M. Svarichevsky had the experience of studying and introducing regional heritage into practice since pre-revolutionary times. In Soviet times, they posed the question of relevance of preserving the continuity of Asian architecture in all aspects from materials and technologies to town planning. They objected to false associations in relation to individual architectural forms characterizing not only cult but also civil architecture against the indiscriminate denial of monumental architecture: "architectural iconoclasm", "ritual background", "architectural bugbear" ${ }^{1}$. The debate was stimulated by sociological directions, which, in the long run, won in Soviet architecture.

\section{BETWEEN TRADITIONS AND INNOVATION}

But in those years, against the use of artistic and aesthetic parameters of historical architecture, the principles of avantgarde artists largely worked. In particular, the principles that were put forward by the ideologist of constructivism M.Ya. Ginzburg in opposition to the heritage of monumental architecture of the past - "Ulugbek architecture" [1]. Having discovered the functionalist parallels to constructivism in the building of the region, he formulated the thesis of the "dwelling of a poor Muslim", as a prototype of buildings of the Soviet people's rule [2].

By programmatically denying the possibility of using any heritage in the conditions of work for the Soviet East, innovators persistently searched for points of contact with the historical architecture (although in the framework of foreign experience). This was due to prospects and an acute need (in what they hardly realized) in the expansion of creative palette of the avant-garde.

\section{FOLK TRADITION IN THE CONTEXT OF PROFESSIONAL ARCHITECTURE - METHODOLOGY}

Democratic directions of socialist culture focused on the heritage. Certain patterns in the process of interaction of professional culture with the traditional were traced. The trend towards the prevalence of style and technological features of modern architecture has manifested itself. Professional and creative models, responding to the demands of socio-cultural situations for the creation of a new environment and "dissolved" traditional prima was rather assumed than evident. The polar point of view - when a set of recognizable attributes of regional buildings (at the level of the plan, volume, construction, material, detail) created an important notion for the psychology of consumer imageemotional contact with heritage. However, the fidelity to samples (although new materials and typology were offered) chained the initiative of architect-professional, depriving the

\footnotetext{
${ }^{1}$ As the unknown archival documents show. See: TsGA RUz. F.R.-2242. Op. 1. Un. st. 94
} 
tradition of development prospects. These creative directions can be conditionally defined as an approach "from the outside" and "from within" national traditions.

One-sidedness of these trends was avoided by those who were able to balance knowledge of heritage (in a wide range from decor to environment) with the outlook of a professional. This provided a charge of innovations. Although they bordered on fantasies, they allowed to destroy the shell of the habitual and the established, restraining the development of traditions in new socio-cultural conditions. The decisive role was played by modern methods, through which filters passed the closest to the advanced ideas of time traditional techniques. Methodologically correct directions characterize the projects for the non-forested areas of A.Bunin, M.Kruglova and "settling nomads of the Kirrepublic" by V.Kalmykov [3]. The authors combined the principles of nomadic (autonomous cells from simple in the assembly of elements) and settled buildings: materials adobe, reed-fiber mat; methods - terraces, three-level space. Modernization has affected volume-planning, constructiveimage characteristics (locking, factory plates, large windows), and, as a consequence, the living conditions have changed 2 . Having transformed nomadic experience and methods of monumental architecture (textured and color processing of the wall, terraces, balconies, loggias), V. Kalmykov used them in the project of the Sport Complex, which has not lost its relevance for us, as well as the "honeycomb" structure of terraced building of multi-storey houses on the foothills [6].

Aesthetically and constructively perfect domed buildings, being a characteristic feature of the architecture of the region - settled (baths, markets, madrassas) and nomadic (mazars, yurts) play the most important role of architectural dominants, and are justified ecologically, saving from overheating. All this the unrealized project of the New Chardjuy planning by the Moscow architects of the ARU brigade took into account [7].

Methods, which have historically justified themselves in conditions of the region, have become a criterion for selecting professional samples from the popular ideas of the innovative architecture of the Center. G. Svarichevsky's 3

\footnotetext{
${ }^{2}$ Interesting in this respect is the foreign experience of those years. "The turn of architecture to the East" was unanimously recognized by the Western press in the 1920s. The central place in this oriental wave was occupied not by the periphrases of oriental decor and forms but by the yurt. For the first time, the type of building that was previously considered the "lower genre" of architecture became a priority. Sensational rotating structure "Solntsevorot" by Riga architects Lekyuye and Zhabo, K. Figuer's dwelling house realized advantages - constructive, economic, functional of nomadic structures. Particular emphasis was placed on the ease of mounting factory plates of the newest materials, economical heating (more than twice). Nomadic dwelling attracted progressive German architect Bruno Taut with its greatest simplicity, aesthetics, comfort and logic of interiors, being rational furnishing. In the series "House of the Future", instead of an expensive stone laying, he used glass or tile roof to the ground, built-in closets, transforming partitions. $[4,5]$

${ }^{3}$ A fine connoisseur of regional architecture, the architect has developed, since the 1910s, alas, unrealized, projects of dome-type buildings: museums (commercial and industrial and arts), series of dwelling houses "Skorostroy" and "Hemisphere". They are made innovative in constructions (ribbed reinforced concrete domes) and function multi-storey public buildings, communal houses.
}

houses-"spheres" are the synthesis of the domes of settled and nomadic buildings of the region and "circular", "ringshaped" buildings of the avant-garde architecture [8] [9]. The innovative design of the linear house-"street" (commune) of the ideal city of the East of Khairkhan project had a regional prototype - "chorsu" with its corridor planning. Close to fantasy works destroyed sociocultural and professional stereotypes chaining the development of tradition. It received an impetus for renewal (innovation), and correct directions towards mutual enrichment of foreign and national and professional and popular cultures that determined the predictive potential of fantasy-projects. But later, they were rejected by professionals in a number of unrealized ideas of avant-garde architecture. They did not receive recognition of the consumer, associating with backwardness, for the public consciousness, the changes and new forms of everyday life were relevant.

\section{HistORY OF MisSED OPPORTUNITIES}

Enlightenment projects of the 1920s, postulated by sociologists and politicians, paved a way for the future. Abstracted from reality, they released fantasy at will. A lot of competitions were held, representing other options for living in the cities of future. The forecasts of "vital activities of peoples of the East" were especially increased. In contrast to the ideas of impersonal exemplary social cities for the entire country, national architecture has shown itself most interestingly in projects for the Eastern republics. Dictated by a special natural-climatic situation, the projects did not attract attention in those years, not having versatility of building techniques for use in other regions.

At the same time, the specific nature of natural environment and associated traditions of Asian architecture have become a powerful filter in selection of ideas, translating almost utopian ideas into a channel close to reality means that the experience of eastern architecture suggested. The positiveness of such a direction is particularly noticeable when comparing the typical project of the town in the areas of watering (the IRTUR project, 1918) and the competitive plannings of social development of the Eastern republics of the 1920s (projects of the ARU, VOPRA, SASS brigades). The contrast is striking. An abstract-cliched layout of scheme (the city-utopia from T. Moor to E. Howard), separated the "natives" and Europeans in the Golodnostepsk project. In the works of the Soviet avant-garde, there is a somewhat naive scale of everyday life reconstruction, but the image of future yet conditioned by local specifics (nature, architecture and life). Essentially, not only was an architectural environment was created, but a new model of life of the nation, in which historical cultural experience, was the defining part of creative search.

The author of one of the most interesting architectural fantasies that remained unknown for a long time, Khairkhan, put forward the idea of a multistoried house-city expanded on the ground, fenced from the desert and the production zone by the canals. Through the utopianism of the ideal model of the city of the East, as a system of street-floors with self-moving sidewalks, an artificial microclimate - a fantasy on the theme of industrial transformations with heat and cold 
centers, anti-dust devices, soil moistening with spray guns, one can see interest in engaging traditional culture. Predicting the city of the East, Khairkhan rightly protected from the destructive influence of the new architecture: "For the emotional constitution of these masses, the ongoing change of life is a catastrophic leap into an unprecedented and unimaginable world" [10]. He was an opponent of "the physical type of buildings that copy the north, harmful to health". He insisted on raw masonry, appealing to the uniqueness of the life of nomads: "For us, a reasonable scheme is not defiled only by the fact that the ancestors reached it with an age-old experience". The architect put forward the idea of continuity of the typology of residential quarter from the "mahalla" (regional agglomeration), using methods of climatic adaptation: the irrigation system (aryks, basins) and streets-avenues, shaded by greens or mat.

The professional press especially emphasized the positive results of architectural forecasting in the above-mentioned contests of socialist cities "for desert regions of Central Asia or settling nomads, where it was necessary to take into account the established forms of life, familiar visual perceptions and local materials, together with common methods of constructing the building" [11]. Dreams about cities of future culminated in a painful "awakening" under the moloch of totalitarianism. The illusion has come to an end. Instead of the garden-towns of Balkhash, Dzhezkazgan, and Karaganda, on the bones of hundreds of thousands of prisoners from a huge concentration camp, architecture that had nothing in common with original plans appeared.

\section{Tradition as An InNOVATION, IN SEARCH FOR NON- STANDARD TECHNOLOGIES}

As time showed, the idea of the house-city of Khairkhan was not so utopian. In the desert of Arizona (USA) year after year, as the scenery of a surreal world of three hundred horizontally spaced individual buildings connected in a complex planning structure, a giant hexagonal house-town of Arcosanti (arcology - a synthesis of ideas of architecture and ecology) was built. The "City of the Future" by Paolo Soleri, the great visionary, is fully viable, demonstrating maximum inclusion of architectural objects and forms in the landscape, without deforming it.

Interpretation of Arab-Muslim domed buildings by Gurley and Borsani resembles G. Svarichevsky's projects. The "spheroid" houses that he proposed for the first time appeared in the Netherlands in the mid-1980s, and there are many of them at the present time. The search for nonstandard solutions continues, for example, houses-"domes", round in plan buildings, as in the $1920 \mathrm{~s}^{4}$. An article devoted to the Muslim cultural complex in Rome, the Palace in Amman (architect Paolo Portoghezi), where not the forms, but European baroque and medieval buildings (ribs) methods with the eastern (including domes) were organically combined, the author named sagaciously "In searching for lost architecture". The critic noted prospects for expanding cultural and professional experience on the basis of appeal to

${ }^{4}$ URL: https://m.geektimes.ru/post/80977/;

http://www.magazindomov.ru/2011/05/15/kruglaya-villa-v-yaponii/ tradition in the wide interethnic and historical-cultural range of the West-Eastern synthesis [12].

Feasibility and the economy of raw buildings have been realized in practice but not in the Asian region. In addition to the Egyptian Fathi, for whom the complexes of raw buildings are a transformed national tradition. Villas, fivestar hotels, and residential complexes in the USA, Australia, Argentina, and Colombia are built quickly, cheaply from terracotta. Contests of "clay architecture" that historically proved its strength (the ancient city of "skyscrapers" Shibam in Yemen; the oldest buildings in Israel - about 9000 years) are constantly held in France. The whole direction of organic, ecological and cheap architecture is underground-overground original houses- "dugouts" (project for NASA of the lunar settlement, housing in England, Japan, Switzerland, the USA, Russia), a wall house ( $230 \mathrm{~m}$ long, out of 12 residences, Australia); geomorphic plastic of the Islamic Art Museum (Qatar), dictated by the landscape of the desert.

Advancing the reality of the use of nomadic tradition in the forecast projects of the Soviet avant-garde has received a second birth in the West since the 1980s. In connection with the energy crisis and the search for new forms of housing, there appeared rotating mansions, buildings with a roof to the ground [13]. Arguments in favor of analogies to nomadic structures are the same as in the debates of the 1920s (microclimate, economy). And the solutions are similar to the "towers" by V. Kalmykov, K. Figher and B. Taut. The argument of energy advantages, forms and designs repeated the directions of the past, although their authors simply could not have known about their predecessors [14] [15] [16] [17]. Since the 1990s and up to present time, there has been a growing interest to the heritage of nomadic architecture in construction of mansions, residential units, mobile buildings (Japan $)^{5}$. V. Kalmykov's idea of "cellular" house found a repetition in Moshe Safdi's construction (Canada, 1967). We do not mean plagiarism but a visionary component of activities of architects who designed for Central Asia.

\section{CONCLUSION}

The introduction of new technologies in the region could solve a whole range of professional and sociocultural problems. In addition to revival of traditional common building techniques that have been preserved and have prospects for improvement, promising savings in means, materials in construction of various in function low-cost buildings and in a short time. Environmental benefits of raw materials, as well as the prospects for rapid reconstruction of morally and physically obsolete buildings are also important. This becomes one of the global problems of $21^{\text {st }}$ century, when cities turn into cemeteries of microdistricts. The architecture of "right angles" and unified technologies, indifferent to local conditions and traditional experience, won. The search for national identity in the region in the late 1930s began to develop on other coordinates, but this is a different topic...

\footnotetext{
${ }^{5}$ URL: http://www.novate.ru/blogs/260309/11714/ ; http://xvastunishka.info/blog/43943396745/Zemlyanyie-doma-PeteraVetsha
} 


\section{REFERENCES}

[1] M. Ya. Ginzburg, 1928. Government House in Alma-Ata (KASSR), Modern Architecture, No. 3. pp. 75-77.

[2] M. Ya. Ginzburg, 1926. National architecture of the peoples of the USSR, Soviet architecture, No. 5-6.

[3] A. Bunin, 1933. Housing for settling nomads of Kirrepublic, Architecture of the USSR, No. 5, pp. 22-23.

[4] H. Wolfensohn, 1925. Housing culture, Building Industry, № 6-7, pp. 471-475.

[5] Turn in architecture to the East, Building industry, 1925. No. 8. p. 561.

[6] V. Kalmykov, 1935. The project of the Central Sport Complex of Central Asia, Architecture of the USSR, No.6, pp. 43-57.

[7] V. Lavrov, V. Popov, 1932. To the problem of urban reconstruction in Central Asia, Soviet architecture, No. 1, pp. 22-33.

[8] G. Krutikov, 1926. Round and semicircular dwelling, Building Industry, No. 9. pp. 617-620.

[9] N. Lukhmanov, 1929. Cylindrical house, Building of Moscow, No. 5, pp. 16-22.

[10] Khairkhan. 1930. Socialist migration of Asia, Revolution and Culture, No. 2, p. 46.

[11] R.Ya. Khiger, K.K. Dzhus, 1929. To the problem of economic substantiation of the dwelling design, Construction industry, No. 8, pp. 673-677.

[12] A.V. Ikonnikov, 1991. In search of lost architecture, Architecture of the USSR, No. 3. p. 108.

[13] Cella Abitable Mobile, Domus, 1979, No. 592, pp. 29-31.

[14] David Wright. 1982. Notes on Energy in Home Design, Architecture and Urbanism, pp. 87-89.

[15] Effimero per vacanse, Domus, 1975, No. 544, pp. 33-36.

[16] An American Dream House, Domus, 1980, No. 610, pp. 42-43.

[17] Temporary Houses, Architectural Design, 1978, No. 4, pp. 234-235. 